\section{Results}

The results are presented in the Table. Of the 42 women taking oral contraceptives $19(45 \%)$ had an E.S.R. above our upper limit of normal, the highest value recorded being $17 \mathrm{~mm}$. in the first hour. None of the patients in the control group had an E.S.R. exceeding $7 \mathrm{~mm}$. The mean value for the E.S.R. in the group taking oral contraceptives was $7.2 \mathrm{~mm}$. in the first hour, compared with 4.0 in the control group, and this difference was statistically significant $(P<0.02)$.

\begin{tabular}{|c|c|c|c|c|c|c|}
\hline & & tero & $. S . R$ & in & Hour) & \\
\hline & $\begin{array}{l}\text { Women } \\
\text { ntrol G }\end{array}$ & & & $\begin{array}{l}\text { n Takin } \\
\text { trtacept }\end{array}$ & & Student's \\
\hline Mean & Range & S.D. & Mean & Range & S.D. & \\
\hline 4.0 & $1-7$ & 1.9 & $7 \cdot 2$ & $2-17$ & $4 \cdot 4$ & $0.02>P>0.01$ \\
\hline
\end{tabular}

\section{Discussion}

The E.S.R. depends on the rate of erythrocyte rouleaux formation, which in turn depends on the plasma concentration of asymmetric macromolecules such as fibrinogen, and to a less extent on $\alpha_{2}$ - and $\gamma$-globulins (Hardwicke and Squire, 1952). Rouleaux formation is probably mediated by a specific plasma protein called "agglomerin," which requires the presence of a supplement of high molecular weight such as fibrinogen for its action (Ruhenstroth-Bauer, 1961). The E.S.R. thus supplies a simple screening test for the presence of raised concentrations of large molecules such as fibrinogen and the larger globulins.

The rise in E.S.R. which accompanies normal pregnancy is attributable to the increased concentration of fibrinogen, which is well documented (Gillman et al., 1959 ; Ratnoff and Holland, 1959 ; Pechet and Alexander, 1961). Similar increases in fibrinogen concentration have been reported in women taking oral contraceptives (Rapaport, 1962 ; Donayre and Pincus, 1965 ; Miller et al., 1965), and this probably accounts for the increased E.S.R. demonstrated in the present study. The effect of hormonal influences on the E.S.R. merits further investigation, however, since Böttiger and Svedberg (1967) have shown that the normal increase in E.S.R. with advancing age is accelerated after the menopause.

These results are reported in order to draw attention to the fact that the E.S.R. may be raised above normal in women taking oral contraceptives and that the isolated finding of a moderately raised E.S.R. is not necessarily an indication for further investigation. Similarly, the assessment of chronic disease by changes in E.S.R. may need to be modified if it is known that the patient is taking oral contraceptives.

\section{Summary}

The Westergren erythrocyte sedimentation rate (E.S.R.) was determined in 42 healthy young women taking oral contraceptives. The mean E.S.R. was significantly higher than in a control group of the same age, and $45 \%$ of the women taking oral contraceptives had an E.S.R. above the upper normal limit for their age.

The finding of a slightly raised E.S.R. in an otherwise healthy young woman taking oral contraceptives is not an indication for further investigation.

ADDENDUM.- Since the above report was submitted for publication E.S.R.s in the range $17-36 \mathrm{~mm} . / \mathrm{hr}$. have been discovered in a further five women taking oral contraceptives who conformed to the above criteria.

Thanks are due to Dr. Nancy Loudon and the staff of the Edinburgh Family Planning Centre, and to Dr. S. H. Davies and the Department of Haematology, Royal Infirmary, Edinburgh.

\section{REFERENCES}

Bochner, M., and Wassing, W. (1925). 7. Lab. clin. Med., 11, 214. Böttiger, L. E., and Svedberg, C. A. (1967). Brit. med. ₹., 2, 85. Brit. med. F., 1967, 1, 742 .

Dacie, J. V., and Lewis, S. M. (1963). Practical Haematology, 3rd ed., p. 408." London.

Dawson, J. B. (1960). Brit. med. 7., 1, 1697

Donayre, J., and Pincus, G. (1965). Metabolism, 14, 418.

Fåhraeus, R. (1918). Biochem. Z., 89, 355.

Gillman, T., Naidoo, S. S., and Hathorn, M. (1959). Lancet, 2, 70.

Greisheimer, E. M. (1927). Amer. F. med. Sci., 174, 338.

Hardwicke, J., and Squire, J. R. (1952). Clin. Sci., 11, 333.

Hilder, F. M., and Gunz, F. W. (1964). F. clin. Path., 17, 292.

Lewis, S. M. (1965). Brit. med. f., 1, 1614.

Miller, S. P., Lee, S. L., and Ritz, N. (1965). Metabolism, 14, 398.

Pechet, L., and Alexander, B. (1961). New Engl. 7. Med., 265, 1093.

Rapaport, S. I. (1962). Thrombo-embolic Phenomena in Women, p. 154 Rapaport, S. I.

Ratnoff. O. D., anc Holland, T. R. (1959). Ann. N.Y. Acad. Sci., 75, 626. Ruhenstroth-Bauer, G. (1961). Brit. med. F., 1, 1804

Westergren, A. (1926). Amer. Rev. Tuberc., 14, 94.

Wintrobe, M. M. (1961). Clinical Haematology, 5th ed., p. 331. London.

\title{
Treatment of Radiation Sickness with Pyridoxine Hydrochloride in Outpatients of a Radiotherapy Unit
}

\author{
H. MATTIE,* M.B. ; E. W. EMERY,† F.F.R. ; I. D. HILL,; B.SC. ; D. R. LAURENCE, $§$ M.D., F.R.C.P.
}

Brit. med. 7., 1967, 3, 215-216

Since Maxfield et al. (1943) reported " most satisfying" results with intravenous pyridoxine hydrochloride in patients with radiation sickness the vitamin has become widely used in this condition, more often administered orally than parenterally (Reeves, 1946 ; Oppenheim and Lih, 1946 ; Wells and Popp, 1947 ; Shorvon, 1949 ; Strahm, 1955 ; Silverman et al., 1956 ; Stoll, 1957 ; Finney, 1961).

However, so far as we know, of the many reports on this treatment only a few are based on properly controlled studies :

* Department of Pharmacology, University of Leiden.

t Department of Radiotherapy, University College Hospital, London W.C.1.

‡ Medical Research Council, Statistical Research Unit, London W.C.1. $\checkmark$ Medical Unit, University College Hospital Medical School, London W.C.1. one study with rather low dosages (Silverman et al., 1956), and another with breast cancer patients only (Finney, 1961). These authors found no difference between pyridoxine and a placebo.

The study reported here was devised in an attempt to reassess the value of pyridoxine.

\section{Design of the Trial}

Since radiation sickness manifests itself as a complex of subjective, of ten vague, complaints, mixed with symptoms due to the original disease or to anxiety, it is obvious that a study of the effect of treatment should be conducted double-blind, and this was done. 
Hitherto in the radiotherapy department of University College Hospital patients who complained of anorexia, nausea, and malaise received pyridoxine treatment routinely, $25 \mathrm{mg}$. t.d.s., direct from the radiotherapist, who distributed it from a central source of supply. If this was insufficient the patients were referred to a physician for further treatment, generally by recognized antiemetics-for example, meclozine, promazine, etc. Our aim was to keep this simple routine intact, and to ask nothing more of the radiotherapist than to keep a record of the patients' complaints and of their drug treatment, for the department is busy and a design interfering with the routine would have been unacceptable. We did not think it proper to use a dummy tablet, as the radiotherapists' general conviction was that pyridoxine was an effective drug. Therefore we used two different dosage levels: 1-mg. and 50-mg. tablets, ${ }^{1}$ at first 1 tablet t.d.s., but the radiotherapist could double the dose on her own initiative if the patient did not respond. Thus the maximum daily dose with the low-dosage tablets-that is, $6 \mathrm{mg}$.- -was somewhat more than the biological need, while with the high-dosage tablets it was $\mathbf{3 0 0}$ mg., which is more than had been ordinarily given in the department.

To minimize interference by other drug therapy we included only outpatients in this trial ; inpatients tend to be on a larger number of drugs, and patients were excluded afterwards if they did take other drugs or if they did not take pyridoxine regularly. Moreover, patients who were treated for diseases of skin or joints were not included, as they are rarely troubled by radiation sickness, so that nearly all patients were being treated for malignant diseases-for example, cancer of the lung or the breast, Hodgkin's disease, etc.

The duration of the whole trial was 24 weeks, divided into eight three-week periods. During each period the central source of tablets contained either all high-dose tablets or all low-dose. There were four periods of high and four of low in the total of eight periods in the order HLLHLHHL. Patients were supplied with bottles containing 15 tablets at a time. Patients ordinarily attended for radiotherapy five days a week.

\section{Results}

Of the 202 patients initially included 19 were excluded, for reasons given above, after radiotherapy was started. Of the remaining patients 94 had symptoms which justified treatment with pyridoxine; 89 patients never needed pyridoxine.

First the effects of high- and low-dose tablets in the dosage of 1 tablet t.d.s. were compared. If the complaints were controlled-that is, it was not thought necessary to give 2 tablets t.d.s.-or remitted on this dosage a "success" was recorded, otherwise a "failure." Twelve patients could not be used in this scheme, as they changed from the high- to the low-dose tablets, or vice versa, between starting and the occurrence of a success or a failure. This was an inevitable consequence of the use of a single central supply source.

$110 \mathrm{mg}$. of ascorbic acid and $0.5 \mathrm{mg}$. of quinine sulphate were added to all tablets to mask the taste of the higher dosage of pyridoxine hydrochlortde.
The remaining 82 patients are included in the following Table :

\begin{tabular}{|c|c|c|c|c|c|}
\hline & & & Success & Failure & Total \\
\hline \multirow[t]{2}{*}{$\begin{array}{l}\text { High dose } \\
\text { Low dose }\end{array}$} & $\because$ & $\begin{array}{ll}. & \\
. & \end{array}$ & $\begin{array}{l}36 \\
22\end{array}$ & $\begin{array}{l}10 \\
14\end{array}$ & $\begin{array}{l}46 \\
36\end{array}$ \\
\hline & & & 58 & 24 & 82 \\
\hline
\end{tabular}

The higher success rate with the high dose $(78 \%$, against $61 \%$ for the low dose) is not statistically significant $(P=0.14)$ at the generally accepted level. If there was no real difference between high and low doses such a result would occur by chance once in seven times.

As the periods in which two tablets were used are inevitably correlated with the preceding periods on 1 tablet t.d.s., we did not think it proper to make any analysis of this dosage. Moreover, the number of failures-that is, when the patient did not improve while taking pyridoxine-was so low that this test would be unlikely to uncover a difference between the two dosages ; 31 patients were treated with the double dose and only 7 of these reported failure ( 3 out of 13 for the high dose and 4 out of 18 for the low dose). This failure rate was much lower than was anticipated from our previous experience (we roughly estimated that half of all patients should need more potent drugs), and we attribute this to the therapeutic enthusiasm of the radiotherapists participating in the trial. As a matter of fact the failure rate was about the same as that in several of the above-mentioned uncontrolled studies $(8-12 \%)$.

\section{Conclusion and Summary}

We think that the practical conclusion should be that treatment of radiation sickness with 1 or $2 \mathrm{mg}$. of pyridoxine hydrochloride orally t.d.s. by radiotherapists who are convinced of its efficacy gives very good results. Whether the effect of this low dose would differ from a placebo remains to be seen.

The effect of the treatment of radiation sickness with pyridoxine hydrochloride was studied in outpatients of a radiotherapy unit. No significant difference between a very low (1 mg. t.d.s.) and a high dose $(50 \mathrm{mg}$. t.d.s.) was detected. When, in case of failure of these doses, the daily dose was raised to $2 \mathrm{mg}$. t.d.s. and $100 \mathrm{mg}$. t.d.s., only a few patients in either group had to be treated with more potent drugs.

We are grateful to Sister Plowman and her staff for their enthusiastic participation; to Miss Kingsbury and her staff ; and to $\mathrm{Mr}$. A. R. Williams, pharmacist to the hospital, who provided the tablets.

REFERENCES

Finney, R. (1961). Clin. Radiol., 12, 229.

Maxfield, J. R., jun., Mcllwain, A. J., and Robertson, J. E. (1943). Radiology, 41, 383.

Oppentology, 41, 47.

Oppenheim, A., and Lih, B. (1946). Ibid., 47, 381. 405.

Reeves, R. J. (1946). Sth med. F. Radiol., 22, 49.

Shorvon, L. M. (1949). Brit. F. Radiol., 22, 49. Silverman, A., Kligerman,

Stoll, B. A. (1957). Ibid., 68, 380

Strahm, A. (1955). Münch. med. Wschr., 97, 855.

Wells, J. J., and Popp, W. C. (1947). Proc. Mayo Clin., 22, 482. 